\title{
The production of Wara cheese from locally sourced coagulants and its nutritional evaluation
}

\author{
Augustine O. Ayeni ${ }^{1 *}$, Opeyemi A. Adeeyo ${ }^{1}$, Oyinlola M. Oresegun ${ }^{1}$ \\ ${ }^{I}$ Department of Chemical Engineering, Covenant University, Ota, Nigeria
}

\begin{abstract}
The use of vegetable extracts as milk coagulants has evolved recently in soft cheese processing. In this study, two types of cheeses were produced from locally sourced raw cow milk using two different coagulants, Calotropis procera leaf and $\mathrm{CaCl}_{2}$. Protein, fat, $\mathrm{Zn}, \mathrm{Mg}$, and $\mathrm{Fe}$ were the nutrients and minerals that were assayed. The protein (18.4\%), Fat (7.93\%), Mg (4.13\%), Zn (4.01\%), Fe (2.59\%) of Calotropis procera coagulated cheese was significantly higher than $\mathrm{CaCl}_{2}$ coagulant produced cheese with protein content of (9.13\%), Fat (5.53\%), Mg (2.34\%), Zn (2.59\%), Fe (1.13\%). The higher ash content in the cheese produced with $\mathrm{CaCl}_{2}$ coagulant makes it susceptible to microbial growth, as a result, reducing its shelf-life. The study suggests that cow milk and Calotropis procera produced cheese appears promising in nutritional contents with further quality improvement.
\end{abstract}

Keywords: Calcium chloride, Calotropis procera, Cheese, Curd, Whey.

\section{Introduction}

Cheese has been defined as a product made from the curd obtained from milk by coagulating the casein with the help of rennet or similar enzymes in the presence of lactic acid produced by added microorganisms, from which part of the moisture has been removed by cutting, cooking and/or pressing, which has been shaped in a mould, and then ripened by holding it for some time at suitable temperature and humidity. The essential ingredients of cheese are milk, coagulants (coagulants cause liquid to thicken or transforms liquid into a soft semi-solid mass), bacterial cultures and salt. The coagulant causes the milk protein to aggregate and ultimately transform fluid milk to a semi-firm gel. When this gel is cut into small pieces (curds), the whey (mostly water and lactose) begins to separate from the curds. Acid production by bacterial cultures is essential to aid expulsion of whey from the curd and largely determines the final cheese moisture, flavor and texture. Cheese is a concentrated source of many of the nutrients in milk The cheese production process is governed by the temperature, acidity, and calcium content of the milk as well as other factors. ${ }^{[1]}$ The robustness of the starter culture during cheese fermentation is enhanced by the presence of a rich consortium of microbes. The optimum temperature established for rennet enzyme as coagulant is in the region of $40^{\circ} \mathrm{C}$, but lower temperatures are normally used in practice, basically to avoid excessive hardness of the coagulum. At this temperature the separation of the curd from the whey is facilitated, it also hardens the curd. The curd may be hardened further by cooking it for a longer period of time, either with or without the whey. The use of vegetable extracts as milk coagulants in soft cheese processing has been known traditionally in some parts of West Africa like Nigeria and the Republic of Benin. ${ }^{[2]}$ Milk coagulants of plant origin have over-ridden the use of animal rennet. The yield and quality of cheese is said to be determined by the quality of the milk used and the type of coagulants. The uses of some coagulants exist in the scientific literature such as sunflower, ${ }^{[2]}$ pineapple, ${ }^{[3]}$ several plant preparations of Cynara cardunculus, ${ }^{[4]} \mathrm{CaCl}_{2} \cdot{ }^{[5]}$

This study was to investigate the effects of a vegetable plant (Calotropis procera, also known as Sodom apple) extract and calcium chloride coagulants on finished cheese. The two coagulants were compared in terms of coagulating strength and the nutritional values of the final cheese products.

\section{Materials and Methods}

Raw material: The raw milk was sourced from fresh whole cow milk through hand milking from white Fulani cows in Ota, Nigeria. The raw milk was pasteurized in order to destroy microorganisms and prevent fermentation, by pouring the fresh milk into $1 \mathrm{~L}$ beaker and heating up to $50{ }^{\circ} \mathrm{C} \cdot{ }^{[6]}$ The Calotropis procera leaves were sourced from the Fulani local cheese producers from a plantation in Badagry town, Nigeria. The calcium chloride used was of the analytical grade.

Experimentation and analysis: The Calotropis procera leaves were weighed and carefully washed with distilled water and sliced with a knife. The leaves were manually mixed with clean water in order for the extract to be collected. The mixture was further sieved to collect the extract. The extract was kept for 2 days in the refrigerator. The supernatant was used as the coagulant. $50 \mathrm{~mL}$ of the extract was added to the warmed $1 \mathrm{~L}$ raw milk in a metallic pot. In addition, $10 \mathrm{~mL}$ of starter culture was added to the mixture (starter culture is a culture of lactic acid bacteria added to the milk in order to acidify it). This determines the characteristic of the $\mathrm{pH}$ of the 
medium. This culture inhibits the growth of undesirable bacteria and also enhances the quality of the drying process. The heating was carried at a regulated temperature of $68{ }^{\circ} \mathrm{C}$ and heating period of $20 \mathrm{~min}$. After the heating period for the clotting to occur, the resulting mixture was cooled to renneting temperature (the temperature most suitable for the milk to coagulate) of $31{ }^{\circ} \mathrm{C}$. The curd was separated from the whey (noncoagulated part of the mixture) using a decontaminated sieve cloth in order not to attract microorganism into the curd formed. $150 \mathrm{~mL}$ of water at $50{ }^{\circ} \mathrm{C}$ was added to the curd with a continuous stirring for $45 \mathrm{~min}$ (temperature was later maintained at $34^{\circ} \mathrm{C}$ during washing process) in order to remove the whey still left with the curd. This was meant to reduce the lactose concentration therefore reducing the acidic content of the curd. Stirring was stopped and the curd was collected in a sieve cloth and left 15 min to drain out the water. The curds were pressed into moulds for the final cheese product (Fig. 1). The analysis of mineral components of $\mathrm{K}, \mathrm{Na}, \mathrm{Mg}$, $\mathrm{Fe}, \mathrm{Zn}, \mathrm{Ca}$ were estimated by using Pelkin-Elmer atomic absorption spectrophotometer. The protein and fat were analyzed by the AOAC analytical methods. In the case of the $\mathrm{CaCl}_{2}$ coagulant, $50 \mathrm{~mL}$ of $2 \mathrm{M}$ calcium chloride was also added. The experiments were replicated twice and the mean calculated. The schematic of the process is as shown in Fig. 1.

Milk

(Protein, fat, lactose, and minerals)

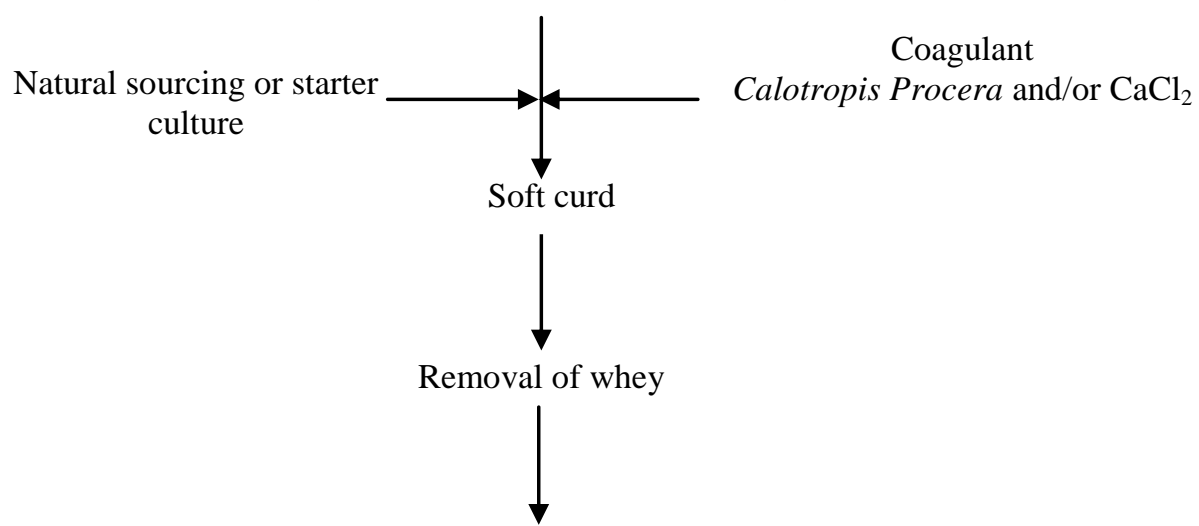

Firm curd

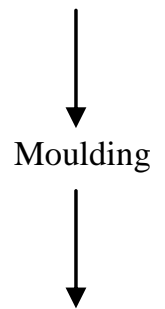

Final cheese product

Fig. 1: Schematic of the basic stages of cheese making

\section{Results and Discussion}

The averages for compositional analysis on the produced types of cheese is as given in Table 1 and Fig. 2. The minerals that were detected by the atomic absorption spectrophotometer were magnesium and iron, indicating that other minerals were present in small amounts or not present at all. Results indicate that the protein content was the highest of the nutritional contents for both types of cheese produced. It was noticed that there was a small difference in $\mathrm{Mg}$ and $\mathrm{Fe}$ contents in the samples of the cheese in which the C. Procera cheese has higher contents in both $\mathrm{Mg}$ and $\mathrm{Fe}$ than with $\mathrm{CaCl}_{2}$. The ash content of $\mathrm{CaCl}_{2}$ processed cheese was higher than the C.Procera processed cheese. Higher ash content could favour the growth and proliferation of microorganisms, thus reducing the shelf-life of cheese. In all, C. Procera showed to be a preferred coagulant to $\mathrm{CaCl}_{2}$. However, the yields needed to be improved upon in future studies by comparing other coagulants Carica papaya (pawpaw), lemon juice, alum and steep water from pap production. ${ }^{[5-8]}$ Based on this study, cheese produced from $C$. Procera coagulant can therefore be used as food supplement in nutritional deficiency of the elements.

Table 1: Nutritional compositions of cheese produced from coagulants (\%) 
The production of Wara cheese from locally sourced coagulants and its nutritional evaluation

\begin{tabular}{|l|c|c|c|c|c|c|}
\hline Coagulants & Protein & Fat & Ash & Zn & Mg & Fe \\
\hline Calotropis Procera & 18.40 & 7.93 & 2.03 & 4.01 & 4.13 & 2.59 \\
\hline $\mathrm{CaCl}_{2}$ & 9.13 & 5.53 & 4.06 & 2.59 & 2.34 & 1.13 \\
\hline
\end{tabular}

$\square$ Calotropis procera $\square \mathrm{CHCl} 2$

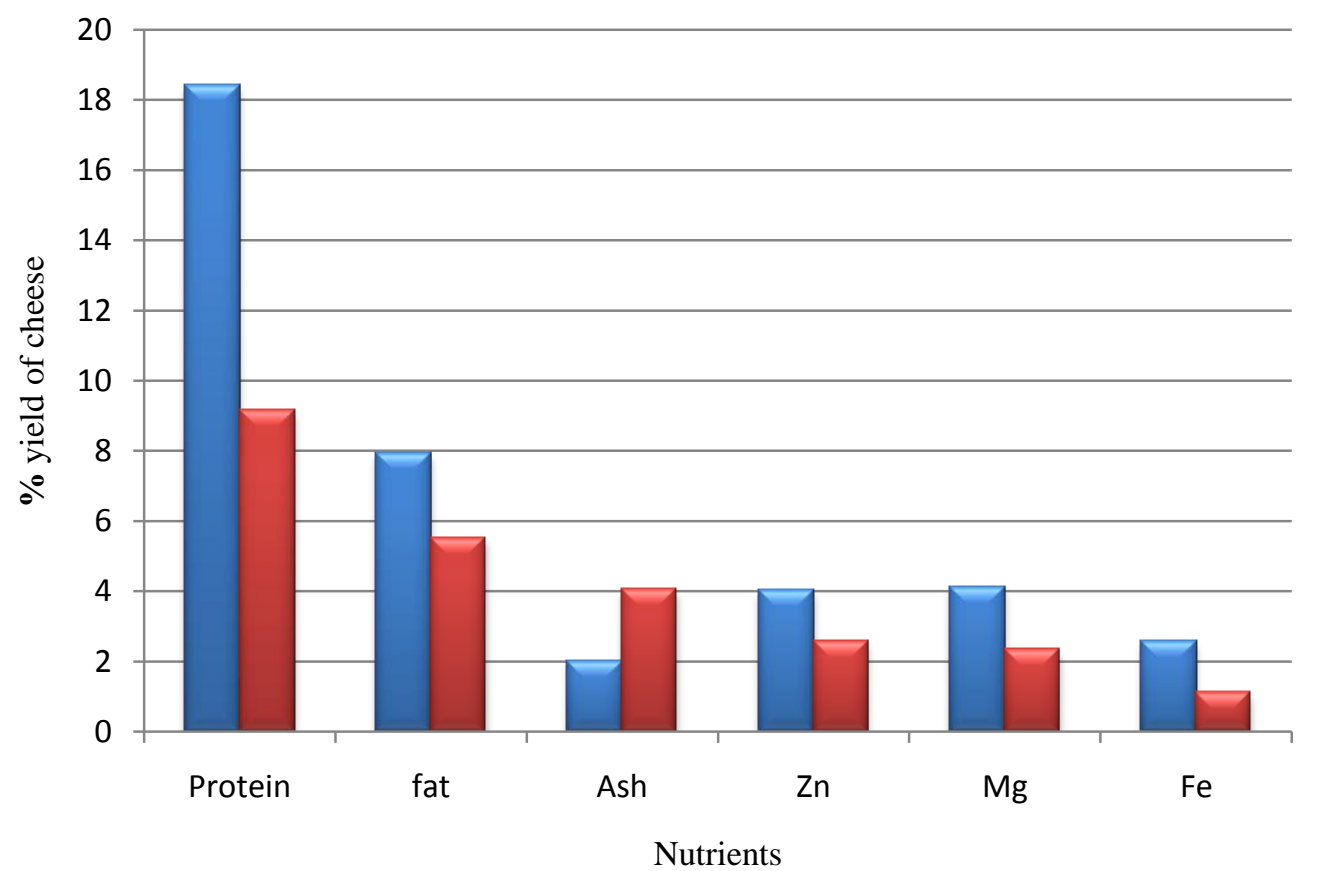

Fig 2. Comparing the nutritional values of cheese

\section{Conclusion}

In this study, it was established that Calotropis procera and $\mathrm{CaCl}_{2}$ could serve as coagulants for the production of cheese. The study further revealed that Calotropis procera has a higher nutritional value to $\mathrm{CaCl}_{2}$ from the finished cheese products. Presence of higher content of ash from the cheese produced from $\mathrm{CaCl}_{2}$ coagulant makes it susceptible to the growth and proliferation of microorganism, thus reducing its shelf-life. However, further investigations are required in order to improve the nutritional value of the final cheese products. In order to increase the yield of cheese, comparison will be made with other coagulants such as lemon juice, Carica papaya, alum coagulated cheese, steep water coagulated cheese. The properties of the cheese obtained from the two coagulants will provide future developments on cheese processing especially the profitability of their local uses.

\section{References}

[1] S.K. Garg and B.N. Johri, Rennet: current trends and future research, Food Review International, 10(3), 1994, 313-355

[2] O.C. Aworth and H.G. Muller, Cheese-making properties of vegetable rennet from sodom apple (Calotropis procera), Food Chemistry, 26(1), 1987, 71-79.

[3] C. O’Connor, Traditional cheese making manual, ILCA, (International Livestock Centre for Africa), Addis Ababa, Ethiopia, 1993, $1-24$.

[4] F. Vieira de Sá and M. Barbosa, Cheese-making with vegetable rennet from cardo (Cynara cardunculus), Journal of Dairy Research, 39(3), 1972, 335-343.

[5] O.E. omotoso, G. Oboh and E.E.J. Iweala, Comparative effects of local coagulants on the nutritional value, in vitro multienzyme protein digestibility and sensory properties of wara cheese, International Journal of Dairy Sciences, 6(1), 2011, 58-65.

[6] A.M. Akinloye and O.O. Adewumi, Effects of local coagulants on the yield of cheese using cow and sheep milk, International Journal of Development and Sustainability 3(1), 2014, 150-161

[7] R. Jenness, Composition and characteristics of goat milk: A review 1968-1979, Journal of Dairy Science, 63(10), 1980, 1605-1630.

[8] T.P Guinee and M.G. Wilkinson, Rennet coagulation and coagulants in cheese manufacture, International Journal of Dairy Technology 45(4), 1992, 94-104. 